\title{
PULMONARY FUNCTION IN BRONCHIAL ASTHMA
}

\author{
By Kenneth M. Citron, M.D., M.R.C.P. \\ Senior Registrar, Institute of Diseases of the Chest, Brompton Hospital, London
}

Asthma is essentially a condition of reversible obstruction in the peripheral part of the bronchial airway. This article describes how the degree of the obstruction to breathing can be measured and how such measurements may be of practical value in the management of asthmatic patients. The time-honoured techniques of inspection, palpation, percussion and auscultation may all give information about the intensity of asthma and are valuable in clinical practice as rough and ready guides to the patient's condition, but are unfortunately subject to gross errors, some due to the observer and some to the patient. Methods which are more objective and accurate yet equally rapid and simple are therefore very desirable and are in fact now available. These methods may be used to give information of practical value about the day-to-day progress of the individual patient and indicate the value of various anti-asthmatic drugs. Evidence of specific allergic causes of asthma and the efficacy of hyposensitization treatment may also be obtained by these techniques.

\section{The Abnormalities of Pulmonary Function in Asthma}

The primary functional disturbance in asthma is bronchial narrowing or obstruction. This may be due to spasm of the bronchial muscles, swelling of the bronchial walls or obstruction of the lumen by mucus. Bronchial obstruction makes the flow of air in and out of the lungs more difficult. In particular, the time required to expel the inspired air is increased. If the expiratory forces are insufficient to expel all of the inspired tidal volume then air will be trapped in the lungs and pulmonary ventilation will be impaired. This hypoventilation may be associated with hypoxia and carbon dioxide retention. Pulmonary emphysema and other structural damage to the lung which sometimes complicates asthma leads to increased insufficiency of pulmonary function and may be associated with pulmonary heart disease.

\section{Pulmonary Function Tests in Asthma}

Pulmonary function tests can, broadly speaking, be divided into four varieties according to whether they test pulmonary ventilation, lung volumes, gas exchange (including diffusion across the alveolar walls and ventilation-perfusion relationships), or the mechanical properties of the lung.

\section{Pulmonary Ventilation}

Dynamic measurements of pulmonary ventila- 8 tion are convenient and also very sensitive indi cators of the severity of asthma and need noe more elaborate apparatus than a recording spiro-? meter.

The forced expiratory volume in one second $\left(F E V_{1}\right)$ is the volume of air expired in one second in a forced expiration after a maximum inspiration. It is a measure of the expiratory flow rate and is a simple repeatable and sensitive test of expiratory obstruction. The FEV 1 is low in asthma and is increased by effective broncho-dilators.

The vital capacity (VC) is the maximal volume of air that can be expired following a maximum inspiration. It is a poor index of the severity of asthma since it is not a dynamic (timed) measurement. Thus, given enough time, an asthmatic may be able to empty the lungs of air satisfactorily so that the VC may be little impaired in asthma and influenced little by effective bronchodilators. (Herschfus, Bresnick and Segal, 1953) The ratio $\mathrm{FEV}_{1}$ is a valuable index of expiratory

$$
\text { VC }
$$

obstruction. It is normally 80 per cent. or more, but is low where asthmatic bronchial obstruction or air trapping due to emphysema is present. Patients with uncomplicated asthma attain a normal ratio when fully recovered, but where asthma is complicated by chronic emphysema the ratio remains low in spite of effective treatment of asthmatic bronchial obstruction (Thompson and Hugh-Jones, 1958). 


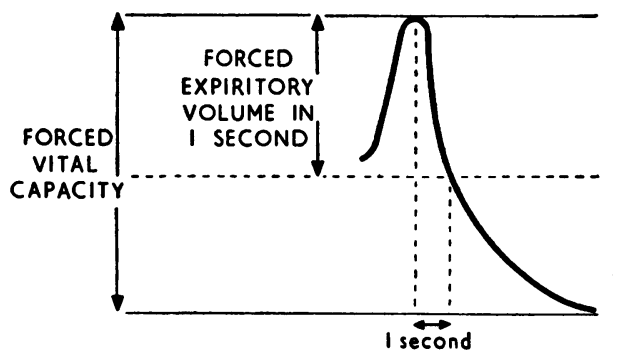

\section{Diagram of Pulmonary Ventilation and Volumes}

The maximum breathing capacity (MBC) is the maximal volume of air that can be breathed per minute. This is reduced in asthma. It is a more difficult and exhausting test for the patient and needs more co-operation than the $\mathrm{FEV}_{1}$ test, and in any case its value can be reliably predicted by multiplying the value of the $\mathrm{FEV}_{1}$ in litres by 35 (Gandevia and Hugh-Jones, 1957). Progressive elevation of respiratory level at the beginning of inspiration in the MBC spirogram tracing to hyperinflation levels is found when air trapping occurs in asthma or emphysema.

The peak expiratory flow rate is reduced in asthma and may be simply measured by a specially designed peak flow meter.

\section{Lung Volumes}

These are sta tic measurements and are usually of much less value than dynamic measurements of ventilation as tests of function in asthma. In asthma (and also in emphysema) the chest is overinflated in the inspiratory position so that the inspiratory capacity is low and the expiratory reserve volume is normal or high. The ratio residual volume/total lung capacity is high (Herschfus, Bresnick and Segal, 1953).

\section{Pulmonary Gas Exchange}

Inadequate ventilation of alveoli which are normally perfused with blood results in diminished oxygen tension and increased carbon dioxide tension in alveolar gas, and this is reflected in systemic arterial blood by hypoxia and hypercapnia. These changes in blood gases are found only in severe asthmatic attacks or where asthma is complicated by emphysema.

\section{The Mechanical Properties of the Lung}

Measurements of intrathoracic pressures by means of intraoesophageal pressure recorders show that during asthma respiratory pressure swings are much increased, becoming very low on inspiration and high on expiration.

The work of breathing, which is measured by the product of the pressure change and the volume change, is greatly increased so causing the patient the sensation of dyspnoea and increasing the oxygen demands of the body.

Lung compliance defines lung stiffness or elasticity and is expressed as volume change per unit of pressure change. Increased lung stiffness, that is low compliance, is usually found in asthma (Segal and Attinger, 1957).

Lung resistance, which is expressed as pressure change per unit of gas flow, is increased in asthma in association with the bronchial obstruction.

\section{The Use of Spirometry as a Guide to Treatment in Asthma}

Having regard to the many changes in lung function in asthma, it is indeed fortunate that simple spirometric tests usually suffice as a practical guide to the management of asthmatic patients. In particular, the forced expiratory volume in one second $\left(\mathrm{FEV}_{1}\right)$ can be recommended as a simple and accurate test. For determining the $\mathrm{FEV}_{1}$ a light recording spirometer of the type described by Bernstein, D'Silva and Mendel (1952) is used. The patient inspires as fully as possible and then expires as fast and as completely as possible. From the spirometer tracing the volume of gas expired in the first second $\left(F V_{1}\right)$ and the total expired (the forced vital capacity or FVC) are estimated.

Comparison of the $\mathrm{FEV}_{1}$ before and after the administration of broncho-dilators gives useful indication of the efficacy and duration of action 
of the drugs in asthma. However effective a broncho-dilator is in general it cannot always be relied upon to help the individual patient because the bronchi may become refractory as a result of previous regular administration of the drug. With ephedrine and isoprenaline tablets in particular a refractory state may develop rapidly when the patient takes the tablets frequently. Thus, if a patient has been taking a variety of bronchodilators it is sometimes helpful to use spirometry to determine which broncho-dilators remain effective in treatment.

Daily recordings of the $\mathrm{FEV}_{1}$ of asthmatic patients in hospital provide a simple objective method of checking the overall effect of treatment and is of particular value in determining the correct dose of corticosteroids. The dosage of corticosteroids required to control asthma is often critical within narrow limits and repeated estimation of $\mathrm{FEV}_{1}$ has proved to be a valuable addition to assessment based on physical examination and the patient's subjective sensations.

The patient's own subjective assessment of the effect of a drug on asthma may be misleading, particularly when the drug has side-effects on the psyche (cf. corticosteroids) or cardiovascular system (cf. adrenergic drugs). This was well brought out in an investigation by Gandevia, Hume and Prime (1957), who compared the effects in asthma of four broncho-dilators, and phenobarbitone and a placebo, assessing the results by the patients' opinions and changes in the $\mathrm{FEV}_{1}$. Whilst the patients were able to distinguish the placebo from the broncho-dilators they rated phenobarbitone as the best drug of all in spite of the fact that it has no effect on lung function. This shows how in assessing their own progress patients are influenced by sensations other than wheezing and dyspnoea, even when they know that it is their ability to breathe which is the object of special study.

Study of the ratio $\mathrm{FEV}_{1}$ or $\mathrm{FEV}_{1}$ is also useful

$$
\text { VC } \overline{\text { FVC }}
$$

in assessing the results of treatment. Thus when the ratio attains $70-80$ per cent. bronchial obstruction has been relieved and no increase in the antiasthmatic drugs is required. However, where asthma is complicated by emphysema the ratio may not become normal even where bronchial obstruction has been relieved because air trapping associated with emphysema produces expiratory obstruction. A persistently low ratio $\mathrm{FEV}_{1}$ when

$$
\mathrm{VC}
$$

the VC becomes normal despite continued treatment suggests that the asthma is complicated by emphysema (Thompson and Hugh - Jones, 1958).
The Use of Spirometry in the Detection of Specific Allergic Causes of Asthma

Study of the response of the bronchi to allergens introduced directly into the respiratory tract is a more direct method of testing for allergic causes of asthma than skin testing. Bronchial testing indicates the sensitivity of the bronchial tree which is the organ directly responsible for the symptoms in asthma.

Bronchial sensitivities may be determined by giving inhalations of aerosols of carbol saline extracts of allergens and making repeated measurements of $\mathrm{FEV}_{1}$ thereafter. A consistent fall of $\mathrm{FEV}_{1}$ greater than any occurring after a previous control inhalation of carbol saline is evidence of bronchial hypersensitivity. The dose of allergen must be very carefully graded according to the patient's clinical condition, skin sensitivity and pulmonary function. Inhalation of an effective broncho-dilator must be given as soon as a reaction becomes evident. Reactions are promptly relieved in this way, but sometimes wheezing recurs later and may be persistent. Rarely there is no immediate reaction but the onset of wheezing is delayed for some hours. Details of the technique are given by Citron, Frankland and Sinclair (1958) They have confirmed that the bronchial reaction detected by this technique indicates specifie hypersensitivity, and that non-specific reaction? do not occur. The response of the individual patient to the same standard inhalation is remarkably consistent.

Bronchial sensitivity tests have been found to be of value in the diagnosis of difficult cases of asthma where the skin reacts to many allergens, but where the history fails to indicate which, if any, of these is contributing to the asthma. Inhalation tests may detect the specific allergic cause and thus aid clinical management, the planning of specific hyposensitization treatment and spare the patient unnecessary injections. Bronchial tests also sometimes detect bronchial sensitivities in patients whose skin tests are negative. This technique is also of value in determining the significance of fungi as allergens in patients with asthma or pulmonary eosinophilia (Citron and Pepys, 1958).

Successful hyposensitization treatment is usually associated with a fall of bronchial sensitivity as detected by this method, and so the test may be useful for investigating the efficacy, rapidity and duration of effect of various methods of hyposensitization.

BIBLIOGRAPHY

BERNSTEIN, L., D'SILA, J. L., and MENDEL, D. (1952),

Thorax, 7, 255 .
CITRON, K. M., and PEPYS, J. (1958), 'Fungus Diseases and their Treatment,' Butterworth and Co., London.

Bibliography continued on page $45^{\circ}$ 
The differential diagnosis of a sarcoidal granuloma in the skin may often be difficult because of the wide range of possible causes (Shelley and Hurley, 1958). The principal ones giving rise to this problem in England are tuberculosis, syphilis, leprosy, leishmaniasis, as well as silica, mercury, and other foreign bodies; most patients with a sarcoid reaction, however, fall into the category of idiopathic sarcoid, whose status as an independent entity is not universally accepted although the Kveim reaction specificity is strong evidence in its favour.

\section{Physical and Vascular Allergy}

There are a wide variety of dermatoses which are usually regarded as being of allergic origin, although this cannot yet be regarded as proven. One example is hypersensitivity to physical agents, such as light, heat and cold, some of which may be drug induced. In some instances of solar urticaria only have antibodies been demonstrated by the passive transfer technique. Substances such as rose bengal, eosin, and haematoporphyrin can greatly increase the reaction of the skin to sunlight without any sign of an allergic mechanism. A distinction has been made between phototoxic and photoallergic reactions, although it is not always easy to differentiate them, especially in the case of some drug photosensitivities like sulphanilamide (Blum, I94I) and chlorpromazine (Calnan, 1958). Although much work has been done to determine the active wavelengths of light in photosensitivity, with the aid of filters or a monochromator, we are still quite unable to define the nature of the allergen which is presumably formed in the skin by the incidcent light, if the reaction is to be regarded as a genuinely allergic one.

A number of skin disorders in which the main histological feature is inflammation and damage to small blood vessels, which cannot be explained in any other way, are now thought to be allergic, and the concept of vascular allergy or allergic vasculitis has arisen. Examples are Nodular Dermal Allergide of Gougerot (I95I), arteriolitis allergica (Ruiter, I953), cutaneous periarteritis rodosa (Miescher, 1956) and the median nasal granuloma associated with renal lesions. The chief evidence in favour of an allergic basis for these conditions is the similarity of the histological findings to known allergic lesions. Evidence of a causal allergen such as acute or focal bacterial in- fection, or drugs is unconvincing, and the patients are not usually responsive to treatment. These conditions are clinically recognizable, but their allergic basis remains questionable.

\section{REFERENCES}

ACKROYD, J. F. (1949), Clin. Sci., 7, 249.

ADAMSON, H. G., and MACLEOD, J. M. H. (1926), Brit. $\mathcal{F}$. Derm., 38, 192.

BLUM, H. F. (I94I), 'Photodynamic Action and Diseases caused by Light,' Reinhold, New York.

CALNAN, C. D., and SARKANY, I. (1957), Trans. St. Fohn's Hosp. Derm. Soc., 39, 28.

CALNAN, C. D., and SARKANY, I. (1958), Brit. F. Derm., 70, 435. CHASE, M. W. (1954), Int. Arch. Allergy, 5, 163.

COCA, A. F., WALZER, M., and THOOMEN, A. A. (I93I), 'Asthma and Hay Fever in Theory and Practice,' Charles C. Thomas, Springfield, III.

COOKE, R. A. (1944), F. Allergy 15, 203

ENGMAN, M. F., WEISS, R. S., and ENGMAN, M. F. Jr. (1936), Med. Clin. N. Amer., 20, 651.

EPSTEIN, S. (1956), Dermatologica (Basel), Ir3, 191.

EPSTEIN, S. (1958), Ibid., II7, 287.

EPSTEIN S. and KLIGMAN, A. (1957), F. invest. Derm. 28, 291

FREY, J. R., and WENK, P. (1956), Ibid., 112, 265.

GANS, O. (1956), Trans. St. Fohn's Hosp. Derm. Soc., 37, r.

GOUGEROT, H. (I95I), Minerva Dermatologica, XXVI I.

HAMILTON, L. D. (1958), N.Y. Acad. Sci., 73 (1), 39.

HARRIS, T. N., HARRIS, S., and FARBER, M. B. (1956), F. exp. Med., 104, 663 .

HAXTHAUSEN, H. (1939), Acta derm =venereol (Stockh.), 20, 257. HERRMANN, F. (1946), Ann. Allergy, 4, 4.

HOIGNE, R., GROSSMANN, W., and STORCK, H. (1956) Int. Arch. Allergy, 8, 103.

INDERBITZEN, Th. (1955), Int. Arch. Allergy, 7, 140.

JADASSOHN, W. (1957), Int. Arch. Allergy, 11, 20.

KIERLAND, R. R. (1955), Amer. Practit. (Philad.), 6, 1089.

KLIGMAN, A. M. (1958), Arch. Derm., 77, 149.

KLIGMAN, A. M. (1958), Ibid., 78, 47, 359.

LANDSTEINER, K., and CHASE, M. W. (1942), Proc. Soc. exp. Biol., 49, 688.

MAYER, R. L. (1957), Int. Arch. Allergy, r1, r.

MIESCHER, G. (1956), Derm. Wschr., 134, 1275.

O'LEARY, P. A. (1953), Sth. med. F. (Bgham., Ala.), 46, 67.

PAPPENHEIMER, A. M. (1958), The Harvey Lectures, Academic Press, New York.

PATON, W. D. M. (I956), in 'Histamine' CIBA Foundation Symposium, Little, Brown \& Co., Boston, Mass.

PEPYS, J. (1951), Int. Arch. Allergy, 2, 147.

PEPYS, J. (1953), Postgrad. med. F., 29, 351, 564.

RILEY, J. F., and WEST, G. B. (1953), F. Physiol. (Lond.), 120, 528 ROSTENBERG, A., Jr. (1955), Amer. Practit. (Philad.), 6, 1094. RUITER, M. (1953), Brit. f. Derm., 65, 77.

SCHNYDER, U. W. (1957), Int. Arch. Allergy, r1, 64.

SHELLEY, W. B., and ARTHUR, R. P. (1955), Arch. Derm. and Syph., 72, 399.

HURLEY, H. J. (1958), Brit. F. Derm. SHELLEY, W. B., et al. (1958), F. invest. Derm., 31, 301.

SNEDDON, I. B. (1958), Postgrad. med. F., 34, 262.

STRAUSS, J. S., and KLIGMAN, A. M. (I957), Arch. Derm.

SULZBBERGER, M. B. (1940), 'Dermatologic Allergy,' Charles C. Thomas, Springfield, Ill.

TUFT, L. (1940), Ұ. invest. Derm., 12, 211.

VON PIRQUET, C., and SCHICK, B. (1905), 'Die Serumkrankheit,' Deuticke, 'Vienna.

WILSON, H. T. H. (1958), Brit. med. F., i, 1378.

WINKELMANN, R. K. (1957), Proc. Staff Meetings of the Mayo Clinic, 32, 329.

ZIMMERMAN, M. C. (1959), Arch. Derm., 79, I.

Bibliography continued from pàge 444-Kenneth M. Citron, M.D., M.R.C.P.

CITRON, K. M., FRANKLAND, A. W., and SINCLAIR, J. D. (1958), Thraox, 13, 229.

GANDEVIA, B., and HUGH-JONES, P. (1957), Ibid., 12, 290.

GANDEVIA, B., HUME, K. M., and PRIME, F. J. (1957), Lancet, i, 956 .
HERSCHFUS, J. A., BRESNICK, E., and SEGAL, M. S. (1953), Amer. F. Med., 14, 23, 34 .

SEGAL, M. S., and ATTINGER, E. O. (r957), ' Clinical Cardiopulmonary Physiology,' Grune and Stratton, New York.

THOMPSON, W. B., and HUGH-JONES, P. (1958), Brit. med. $₹$., i, 1093 . 